\title{
Regulatory theater in the pork industry: how the capitalist state harms workers, farmers, and unions
}

\author{
Ivy Ken ${ }^{1}$ (D) Kenneth Sebastian León ${ }^{2}$ (D)
}

Accepted: 21 January 2022 / Published online: 7 February 2022

(C) The Author(s), under exclusive licence to Springer Nature B.V. 2022

\begin{abstract}
The United States pork sector generates billions of pounds of food and billions of dollars of sales and tax revenue per year. This industry has also generated hundreds of workers' deaths from covid infections, thousands of workers' injuries from hazardous working conditions, economic and environmental depletion of communities near production sites, and the massive decline of small hog farming operations - not to mention over a billion tons of fecal waste per year. Although pork companies, like most firms in the food industry, portray state regulation as a burden for commercial interests, we identify how the pork industry enjoys a symbiotic relationship with the state to create favorable conditions for three interrelated processes: 1) monopoly and monopsony power; 2) hyper-efficient but injurious working conditions; 3) union busting. Using structural contradictions theory, we explain the failure to protect workers, farmers, and communities as a feature of the fundamental contradiction between protection and accumulation within the capitalist state. We argue that the solution to pork industry harms is not more regulation but the outright replacement of currently existing capitalism.
\end{abstract}

Keywords Pork industry $\cdot$ Meatpacking $\cdot$ State-corporate crime $\cdot$ Structural contradictions $\cdot$ Unions $\cdot$ Capital $\cdot$ Regulatory theater

Ivy Ken

ivyken@gwu.edu

Kenneth Sebastian León

kenneth.sebastian.leon@rutgers.edu

1 Department of Sociology, George Washington University, Washington, DC, USA

2 Department of Latino and Caribbean Studies and Criminal Justice Program, Rutgers University, New Brunswick, NJ, USA 
As with many global food system enterprises, companies in the U.S. pork industry are regularly investigated and sued for practices that violate the law. ${ }^{1}$ These efforts speak to the existence of sociolegal mechanisms for curbing excesses in this industry. Legalistic frameworks, though, often distract from structural harms that are endorsed, incentivized, and facilitated by the state. For that reason, criminological inquiry that is limited to legally recognized administrative, civil, or criminal violations is insufficient. In the present study, we highlight the state-corporate symbiosis whereby pork packing companies engage in legal practices predicated on knowable, predictable, preventable, and legitimized harms. Using a state-corporate crime perspective, where reliably harmful outcomes serve as the basis for inclusion as a criminological phenomenon, we detail the ongoing performative spectacle in which the state, which is ostensibly meant to prevent, regulate, and remediate any harms perpetrated by corporations in the pork industry, instead bestows legitimacy to the project of capital accumulation. This regulatory theater distracts from the symbiotic pursuit of capital, leaving publics, pigs, and the planet vulnerable. We employ structural contradictions theory, which underscores the state's interest in legitimizing high thresholds for harm in service to corporate profit maximization.

The harms faced by U.S. meatpacking workers due to the coronavirus pandemic have been covered in recent works on U.S. food systems (Ken \& León, 2021; Knox, 2020; Philpott, 2021). We build on this as part of our contribution to the burgeoning scholarship connecting criminology with critical food studies. The paper begins by establishing that corporations and contemporary states share the goal of capital accumulation. We then examine three specific phenomena where the state's facilitation of the harmful and even deadly (but not always illegal) actions and tactics of pork sector companies allows the industry to reap hulking profits. Those phenomena are 1) monopoly and monopsony concentration, 2) working conditions in pork packing plants, and 3 ) the historical crusade to de-unionize the industry. ${ }^{2}$ We explain the state's failure to protect workers, consumers, and farmers as the result of performative governance, where states act in ways that detract from the symptomatic and iterative contradiction between liberal statist governance and capitalism. On the basis of this analysis we conclude that the solution to harm in the pork industry is not simply a more convincing performance of regulatory theater, but a fundamental change to a more sustainable political economic system.

\footnotetext{
${ }^{1}$ For example, a major pork packers have been sued repeatedly for systemic gender, religious, and racial employment discrimination (Gutierrez, 2018), price fixing, and collusion (Douglas, 2019).

${ }^{2}$ State-corporate symbiosis is arguably also present in the legal scope of animal cruelty legislation-for example, in the exclusion of animals raised for consumption from the federal Animal Welfare Act-but this falls beyond our current scope.
} 


\section{The pork industry - A critical food systems overview}

Pigs and the disassembly and reassembly of their body parts (i.e., processing and packing) is big business. Often referenced with terms like "the Global Mega Producers," multinational giants like Smithfield Foods, Tyson Foods, and JBS together generate billions of dollars in annual revenue. Pigs are monetized at various stages of their lifecourse, and their death and disassembly are just one section of their commercialization. At birth, a piglet is typically owned by a multinational processing company and raised by a contracted farmer. The piglet's mother, who was artificially inseminated and lives in a 2-foot-wide indoor gestation crate with a slatted cement or plastic floor to facilitate the flushing of manure into an adjacent lagoon, nurses the piglet and its siblings from a separate metal crate until they each reach ten pounds. They are then shipped to a "wean-to-feeder" facility to gain weight, and then to a "finishing/feeder" tunnel barn where they join up to 8,000 other hogs until reaching the "ideal slaughtering weight" of 280 pounds. Their feet will likely never touch grass.

These functions are considered part of farming or producing the pig, and the farmers along the way are likely "contract feeders" who are paid by the "pig space" in their facilities. Contract feeders are the independent farmers of folkloric Americana who, in order to survive in the pig producing business since the 1990s, have had to enter into binding, confidential, year-to-year agreements with packing companies and rebuild their farms according to the packing companies' specifications (Ackerman \& Musil, 2018).

Market forces or consumer demand never prompted the scale of industrial pork processing. Demand is vigorously cultivated through industry lobbying, culture campaigns, and government subsidies. The scope and scale of these efforts are so gargantuan, and yet so normalized, that describing how products such as pork chops, hot dogs, bacon, pork sung, and spam come to market might seem alarmist, if only because there is a cognitive gap between what people eat and how it is made. Deliberately kept from public view (Fitzgerald, 2010), pork "packing" and "processing" are euphemisms for sawing animals apart, deboning them, severing their veins, removing their brains, skinning, slitting, eviscerating, hook-hanging, draining, stunning, and grinding their corpses. Workers on the disassembly line engage in repetitive motions with knives, saws, knocking guns, screw augers, snout pullers, belly presses, circular saws, and other power tools in plants that are cold and often have slippery floors from the animals' fat. The instruments workers must use, and the profit-maximizing imperative to use them efficiently, makes this inherently dangerous work (Lander et al., 2010).

Laborers are impacted not only by the industrial methods used inside these plants, but their geo-political distribution. In the early twentieth century, major plants existed in cities like Chicago, Cincinnati, and Omaha, where at one point 90 percent of meatpacking workers had union contracts (Brueggemann \& Brown, 2003), offering living wages and safer working conditions (Horowitz, 2002). In the 1970s, a company called IBP bought and closed major unionized plants and moved the work to smaller towns, mostly in right-to-work states 
(Fitzgerald, 2009), ushering a new wave of industry-wide competition to lower labor costs. At least one company even bought unionized plants from itself only to re-open them as non-union shops (Horowitz, 2002). Crucially, before IBP, when rates of unionization were high, slaughterhouse wages were higher than wages in any other manufacturing jobs (Human Rights Watch, 2019a). By 1990 wages in the meatpacking industry had dropped to 20 percent below general manufacturing work (Fitzgerald, 2010); today they are 44 percent below (Human Rights Watch, 2019b). Median hourly wages for frontline workers range from $\$ 12.69$ to $\$ 14.45$, depending on specific role (Bureau of Labor Statistics, 2018).

Critical food scholars have long questioned the compatibility of meat production and consumption with ecological sustainability (Stoll-Kleemann \& O'Riordan, 2015; Tilman \& Clark, 2014), even while the pork industry continues to grow (Haley, 2021). In addition to polluting waterways with bacteria and chemicals from massive amounts of hog feces, industrial hog production facilities put workers and nearby residents at higher risk of kidney disease, asthma, and infant mortality (Chrisman, 2020). Concentrated agriculture feeding operations (CAFOs) are often located in majority Black and Latina/o counties; people of color in North Carolina are 152 percent more likely than whites to have an industrial hog production facility and its harms near their homes (Wing \& Johnston, 2014). To this local-level environmental racism, add the world systems aspect of commodity chain politics, in which coercive labor regimes in the U.S. and peripheral countries exploit Black, Latina/o, and Indigenous workers to produce food for the most racially and economically advantaged in the Global North. While profits pile up, workers on the front lines of the industry do not benefit from the riches of their labor.

Given these well-established and documented harms, where is the government? Where is the law? In many cases, local, state, and federal governing bodies and laws make these structural issues worse. For example, US states have sought to "accelerate" pork industry growth by suspending capital gains taxes and providing tax incentives to pork companies that construct or remodel large industrial facilities, even over the vigorous opposition of residents (e.g., Kansas Department of Agriculture, 2020). In line with this, amidst the global coronavirus pandemic in 2020, former President Donald Trump enacted an executive order that declared the meatpacking industry "critical" and pressured state departments of health to allow packing plants to remain open, resulting in massive spikes in infection and hundreds of workers' deaths (see Ken \& León, 2021).

These are just two of thousands of examples of the state acting to protect and support the pork industry, despite democratic opposition and measurable harms. We focus on three additional realms shaped by state-corporate symbiosis: (1) the industry's consolidation and market concentration; (2) working conditions in the industry; and (3) the de-unionization of the industry' workforce. We place these impacts in the context of state-corporate power and consider the structural contradictions that motivate the symbiosis between these state and corporate imperatives. 


\section{State-corporate symbiosis}

Criminal law is a state product. In the United States, all three branches of government - at both state and federal levels - shape the political boundaries of what constitutes crime, and the mechanisms (or absence of mechanisms) for their enforcement. Preventable harms associated with routine business practices are traditionally outside the scope of the criminal justice system, where interpersonal and property-based street crimes are prioritized (Michalowski \& Kramer, 2006). Thus, a wide range of massive and preventable harms and abuses of power have been outside of the formal legalistic and political boundaries of criminological inquiry (see Gordon \& Green, 2021; Michalowski, 2016; Quinney, 1970; Schwendinger \& Schwendinger, 1970). These definitional and political tensions intrinsic to studying state crime, corporate crime, and state-corporate crime are apparent within and beyond criminology (Hillyard \& Tombs, 2007; Matthews \& Kauzlarich, 2007).

Our present focus is the normative, procedural, and symbiotic production of empirical harms, or the measurably injurious-yet legal—business activities that various stakeholders might defend as either normal or necessary (see León \& Ken, 2019; Tombs, 2012). In this, good business practices and systematically harmful practices can reflect the same phenomena, and there is no deterministic consistency in state actions. The state can initiate actions and intervene in ways that produce and mitigate harm, and the state can fail to effectively uphold existing laws and regulations (Kauzlarich et al., 2003). The state also engages in material and ideological work to establish an acceptable "idea of what constitutes 'feasible' regulation" (Tombs, 2012, p. 186 emphasis in original). This, in turn, influences how low levels of regulation are normalized as desirable, healthy, and "good for the economy."

A nascent but rapidly growing sub-area within criminological analysis, as indicated by this special issue, audits the harms of contemporary food systems at various scales (see also Cheng, 2012; León \& Ken, 2017; Lord et al., 2017). The limitations of criminological inquiry based on state-centric definitions of crime are well established in critical criminology generally (see Chambliss, 1989; León, 2021; Schwendinger \& Schwendinger, 1970) and in "food crime" scholarship specifically (Croall, 2013; Leighton, 2016; León \& Ken, 2019; Spink \& Moyer, 2011). In line with critical criminology and critical food studies, we explore the paradoxical expectation that the state should regulate, control, or mitigate the normalized predations of food sector corporations while simultaneously protecting, legitimizing, and advancing the interests of those same industries.

State-corporate power (Bernat \& Whyte, 2017; Kramer et al., 2002; Pearce, 1976 ) is not sought or applied at random, but in furtherance of capital accumulation. Applying this perspective to criminological inquiry is most compatible with structural contradictions theory (see Chambliss, 1975; Chambliss \& Zatz, 1993). Typically associated with analyses of political economy and criminal law (e.g., Kramer, 2016; Rodriguez \& Barlow, 1999; G. Ward, 2015), this theory allows for the direct integration of some of the most egregiously conflicting and ethically 
incoherent features of contemporary food systems, which moves us from describing to explaining some of the enduring harms produced by state-corporate symbiosis in the pork industry.

\section{Structural contradictions theory}

Liberal nation states and capital accumulation projects are extensions of one another. States have helped secure predictability and administrative rationality for capitalist modes of social and political organization, conferring legitimacy through procedural and distributive structures such as ownership protections, tax policies, and employment contracts. Structural contradictions theory centers the relationship between a state's prescriptive political values, such liberties and rights, and the material features that enable the state to function (Chambliss \& Seidman, 1971). Given the scale and unwieldiness of this framework, an appropriate empirical anchor is required. Specifically identifying how the state initiates and facilitates capital accumulation projects is vital for untangling the breaches of values stemming from state-corporate symbiosis, and for demonstrating the ultimate futility of corporate regulation under capitalism.

Representatives of capital interests often frame the government as a nuisance that should "get out of the way" to "free up" innovation and commerce. At various periods of US history, the state-across both major political parties-has provided favorable regulatory climates for business (Friedrichs \& Rothe, 2020). Since the 1970 s, one of the key means through which the government has enacted "an across the board drive to reduce the scope and content of federal regulation of industry, the environment, the workplace, health care, and the relationship between buyer and seller" has been cutting the budgets of regulatory agencies and appointing " "antiregulatory, industry-oriented agency personnel' to key positions" (Edsall, 1985; Harvey, 2007, pp. 51-52). For those concerned about the harms that have ensued under these conditions, the obvious solution would seem to be to re-invest in regulation: make regulations more robust, re-empower regulatory agencies, and make punishments harsher.

Narratives of "deregulation" inadvertently obfuscate the degree of symbiosis required to establish a neoliberal climate. The state has not withered away or fallen back to allow market forces and capital interests to organize social, political, and civic life. The state has, rather, robustly invested in capital interests and acted in ways that protect and secure them. Creating and maintaining the infrastructure for capitalists to operate "unfettered" requires state actors to engage in a great deal of facilitative and defensive activity (Harvey, 2007). The state does not "get in the way" but rather paves the road by standardizing, rationalizing, legalizing, and providing legitimacy to enterprises that are within the "national interest." This is part of the symbiotic framework that is central to our analysis of state-corporate power. Since the "accumulation of capital determines a nation's power, wealth, and survival today, as it did 300 years ago" (Chambliss, 2009, p. 52), we must pay particular attention to the ways the state initiates and facilitates capital, and the contradictions 
that emerge from presuming that the state is somehow divorced from-or fully capable of acting against—capital interests.

Labor costs slow the rate of capital accumulation. Though the basic framework of capital "versus" labor often implies that the state is somehow a neutral arbiter in structuring this relationship, meatpacking companies have maximized profits in large part by consolidating, legitimizing indefensible working conditions, and systematically undermining unions. Politicians and regulatory entities are not passive or neutral in this process, as an industry can only accomplish these things with the material and ideological backing of state actors. To be clear, these are structural forces that transcend any individual CEO, any individual governor or city council, and any individual regulatory executive. For this reason, it is important to distinguish between crimes or deviance committed by "elites" who, by virtue of their economic position, have access to the levers of political power, and the criminogenic nature of corporations, themselves (Mills, 1956; Tombs \& Whyte, 2015).

A criminological analysis that focuses on harm must also attend to the substance and nature of criminal laws, and the theater in which they are-or are not-enacted and enforced. In our applied setting, laws meant to prevent corporations from engaging in harmful activities are generally defined in such a way so as to ignore the bulk of empirically devastating impacts of "normal business." If a state's relative power is dependent on its ability to protect and strengthen capitalist interests, and not on the well-being of the people and the integrity of the ecological space that it governs, we would not be surprised to find the state initiating, facilitating, allowing, and condoning corporate actions even when-legal or illegal—those actions are unequivocally harmful.

By treating the state and industry as separate entities here, we problematize the dichotomy between them and question the notion that the public can rely on a state to protect capital and non-capital interests equally. We frame state interventions that cut against capital interests as "regulatory theater" to invite critical inquiry into how state representatives and corporate actors are collaborators in a consensual drama, where both "sides" work towards the same goal despite their public-facing roles, which might seem adversarial.

The concept of regulatory theater also allows us to account for the messy and contradictory nature of "the state," itself. As an ensemble of institutions and actors at different levels of government with different priorities, the state will never act uniformly or uncontested. This does not diminish the ongoing symbiotic relationship it has with capital, however. In fact, the battles and divisions within government and between different state actors may confer legitimacy on the symbiotic relationship it shares with corporations. New laws may be passed as part of acute dilemmas; Congressional hearings may seek information about corporate practices; lawsuits may be adjudicated; and individual state governments may clash with the federal government over how corporations and employment contracts should be regulated. Critical criminologists have argued that state interventions are part of a dialectic process of addressing heightened conflicts, but in ways that "maintain the capitalist system without fomenting a revolution" (Chambliss, 1979 , p. 153). As a bit of performative governance (Ding, 2020), these interventions and their limited impact offer material for understanding regulation as a 
process of simultaneously conceding to and co-opting stakeholders that wish to shape the law in directions that are not aligned with capital interests.

Thus we have symbiosis and contradiction. What is contradictory is the presumption that the state can competently protect the lives and liberties of the populace or the health of the environment while also cultivating a symbiotic relationship with capital. In what follows we briefly describe our interpretive case study parameters before analyzing three primary activities in which the structural contradictions apparent in the state-corporate symbiosis of the pork packing industry are apparent: consolidation, the administration of hazardous working conditions, and de-unionization.

\section{Analysis}

Harms in the pork industry are legion and calls for regulatory reform are constant, but the situation for workers, farmers, consumers, and the environment only seems to get worse. Thus, we treated the pork industry as a case and sought to identify (1) how the industry came to be structured as it is, (2) how day-to-day operations run, and (3) what actions have most affected workers and communities involved in the industry. We focused on these dimensions with an eye toward identifying evidence of symbiosis or lack of symbiosis between the state and pork companies, in both recent actions and ongoing relationships (Tombs, 2012). This required attention to the actors, processes, institutions, and mechanisms involved, and a search for coherence and sequence among them (Stake, 2005).

To inform our case we compiled newspaper articles, magazine articles, blogs, non-profit organization reports, industry marketing, US Senate hearings, Presidential Executive Orders, US Chamber of Commerce communications, union press releases, and published survey research. We purposively sampled sources reflecting multiple vantage points and constituencies, including materials produced by the industry, unions, the state, interest groups, non-profit organizations, and journalists. We anchored our analysis in the historical patterns of the pork processing industry by integrating peer-reviewed journal articles, scholarly and popular books, and the direct text of federal and state laws concerning the evolution of the US pork industry. In approaching each of these sources, we took a skeptical stance and attempted to verify all facts, audit the discourse of what was and was not emphasized, and assess how the totality of the evidence supported narratives and positions by various interest groups.

In what follows we present our analysis of the specific ways the highly profitable pork industry and the state have acted symbiotically to (1) consolidate the industry in anti-competitive ways, (2) administer inhumane working conditions, and (3) structurally configure the industry to repel unionization. We detail the regulatory theater enacted in these realms and use structural contradictions theory to explain why the state has allowed and facilitated these harms rather than enacting effective protections for workers, farmers, consumers, and the environment. 


\section{The harms of concentration}

The slaughter, processing, and packing of hogs (hereafter, "packing") has become a highly concentrated and powerful industry. The four-firm concentration ratio (CR4) is used as a measure of the combined market share of the largest four firms in an industry, and a CR4 above 50 percent in any market is considered uncompetitive (USDA, 2017). The CR4 for pork packing in 1976 was 32.9 percent; by 2016 it had more than doubled, to 71 percent (C. Ward, 2010; Woodall \& Shannon, 2018). Although packing firms contend that consolidation brings efficiencies that save consumers money, the price of pork has increased with consolidation even as the prices these firms pay to farmers for pigs have fallen (Food \& Water Watch, 2011).

Vertically, companies have been particularly aggressive in their acquisition of entire farming operations, the expanded use of CAFOs, and the rapidly diminished viability of small hog farmers. The monopolistic character of the pork industry (few sellers, many buyers) has been well studied (see Corey, 1950; Kolko, 1963; Virtue, 1920), but it is also relevant consider the industry's internal monopsonist character (few buyers, many sellers). A monopsony is an anti-competitive arrangement through which a small number of highly concentrated firms (the buyers) actively construct a market of extremely limited selling options, in this case for small and independent pig producers. ${ }^{3}$ Pork packing companies demand contractual arrangements that allow them to buy pigs without competitive bidding, because few other buyers actually exist that could compete at any stage of the supply chain. Mergers, acquisitions, and buyouts have eliminated any serious competition. The monopsony framework puts downward pressure on prices paid to farmers, and structurally incentivizes additional efficiency-maximizing practices to be used by those farmers in order to meet those rates (Food \& Water Watch, 2011; Woodall \& Shannon, 2018). The National Sustainable Agriculture Coalition (2021) argues that, "Fair negotiation is simply not a realistic option for small growers under these conditions." The exploitative nature of contract and subsidiary arrangements has buried small, independent hog farmers, since the packing companies prefer to contract with large farms that can meet these price points and scales of production (Mock, 2020).

This monopoly/monopsony dynamic also applies to labor in the industry. CAFOs have increasingly located in areas where jobs are scarce and income levels are low (Wendee, 2013), so highly concentrated sellers of pork products also become the de facto consolidated buyers of labor. Not only are pig farmers beholden to the prices set by pork mega-corporations, but packing and processing workers have very few options other than the local pork plant to which they can sell their labor (Kandel \& Parrado, 2005). Packing companies deliberately locate in just such areas (Warren, 2020). These are just some aspects of the pork industry's anti-competitive structure that are protected and encouraged by the state through a range of executive, legislative, and judicial levers.

\footnotetext{
${ }^{3}$ Prior to the 1990s, 87 percent of hogs were sold in competitive markets, allowing small and independent hog farmers a viable path as market actors. "Today that figure is less than seven percent" (Kelloway \& Miller, 2019, p. 4).
} 
All branches of government are implicated in the regulatory theater that enhances this industry's concentration. The legal frameworks that govern competitive market dynamics, for example, have failed to adequately mitigate the monopolizing tendencies of capital in the pork industry (Gunderson, 2011). Antitrust laws have been on the books for over 100 years, and yet, the "judicial embrace of efficiency and pro-competitive rationales for antitrust law" limits its effectiveness (Lauck, 1999, p. 453). The Federal Trade Commission was originally created to mitigate extensive profiteering and concentration in meatpacking, specifically. The agency issued a report in 1919 confirming the unlawfulness of the industry's practices, to little effect (Federal Trade Commission, 1920). Calls for regulating stockyards and livestock as public utilities go back over a century (see Virtue, 1920), with corresponding legislation like the Packers and Stockyard Act of 1921, meant to directly curb meatpacking's anti-competitive excesses. One hundred years later, concentration has worsened (Food \& Water Watch, 2011).

While passing laws and creating regulatory agencies may seem like "victories" against industry-wide harms, the operationalization and enforcement of those laws exemplifies regulatory theater. For example, the United States Department of Agriculture (USDA) joined with farmers and advocates in the early 2000s to get Congress to use the 1921 Packers and Stockyards Act to approve clear criteria for determining the industry's anti-competitive actions against farmers. This would seem to indicate that state actors can competently advance the interests of farmers, workers, and other constituents. Yet after decades, the criteria remain unapproved. As President, George W. Bush "essentially halted enforcement" of the Packers Act entirely; Barack Obama abandoned reforms to the Act at the end of his presidency; and Donald Trump worked with the USDA to fully and promptly discard the Act's rules (Khan, 2012; Lilliston, 2017).

Confusing and inconsistent actions such as these by different state entities might suggest an ebb and flow to the state's relationship to capital, or the proper functioning of checks and balances, presenting a challenge to the symbiosis argument. Still, evidence that this is merely regulatory theater lies in the final act, which is consistently repeated: the state's actions rarely result in any real challenge to the underlying capital accumulation project. The state creates showy legal and bureaucratic frameworks to respond to specific conflicts, but harm continues as the state-across political parties-also provides favorable regulatory climates. Add to this the long ideological work involved in producing judicial decisions centered on efficiency instead of harm, and legislative language that allows packing firms to enact any "reasonable business decision that would be customary in the industry" (National Sustainable Agriculture Coalition, 2021), and what is left is the distracting drama of performative governance. In what follows, we focus on two other areas where state-corporate symbiosis in this industry directly affects workers: working conditions and unions.

\section{The harms of working conditions}

The de-skilling of work in the animal disassembly line is intentional and consistent with best practices in industrial engineering, bringing a type of efficiency that allows 
employers to lower wages and decrease dependency on any single worker. By being structurally situated as readily replaceable, the laborer becomes an interchangeable and thus disposable input. Meatpacking jobs are among the most hazardous in the US, with the highest rates of injuries and illnesses of all occupations (Lander et al., 2010). Physical injuries are well-known, but workers, of course, watch and participate in thousands of gruesome animal deaths each week and also face psychological harm, including a form of post-traumatic stress disorder. An employee whose job is to slit the throats of hogs to cause them to bleed to death told a journalist about his fellow hog stickers' problems with alcoholism: "They have to drink," he said. "They have no other way of dealing with killing live, kicking animals all day long. If you stop and think about it, you're killing several thousand beings a day" (quoted in Dillard, 2008, p. 397).

Further, workers are regularly exposed to pathogens known to increase the risk of disease infection, as well as to anti-microbials that can impair their immune system. For example, a "highly corrosive toxic chemical" called Peracetic Acid gets sprayed on carcasses in processing plants (NELP, 2018). This acid irritates workers' eyes and skin, causing rashes, burns, and irritation to the respiratory system which results in coughing, difficulty breathing, and asthma - effects known even before the coronavirus pandemic. OSHA - the Office of Safety and Health Administration within the US Department of Labor-does not currently regulate or monitor the use of this acid in meatpacking plants, even while the agency acknowledges the "serious safety and health hazards" of this industry:

These hazards include exposure to high noise levels, dangerous equipment, slippery floors, musculoskeletal disorders, and hazardous chemicals (including ammonia that is used as a refrigerant). Musculoskeletal disorders comprise a large part of these serious injuries and continue to be common among meat packing workers. In addition, meat packing workers can be exposed to biological hazards associated with handling live animals or exposures to feces and blood which can increase their risk for many diseases. (OSHA, n.d.)

"These places are injury factories," according to one former head of OSHA (Hiltzik, 2020). Precariousness and efficiency are nevertheless normalized in both occupational practice and state policies.

A further point of contention between workers and employers is "chain speed," which is both central to a company's profit and a consistent source of workplace injuries. One worker described the clash: "The line is so fast there is no time to sharpen the knife. The knife gets dull, and you have to cut harder. That's when it really starts to hurt, and that's when you cut yourself" (Human Rights Watch, 2005, p. 24). Although injuries like this are not unusual or uncommon, chain speeds have only increased. The production lines at a Hormel plant in Minnesota, for example, ran 900 pigs per hour in 2002. By 2007 they ran 1,350 pigs per hour - a 50 percent increase in output with only 15 percent increase in labor (Genoways, 2014). Similarly, a Smithfield plant in North Carolina-the largest hog killing plant in the country-employed up to 5,000 workers and processed 25,000 hogs a day in 2003. By 2018 with the same number of employees it was processing up to 35,000 hogs a day (Human Rights Watch, 2019b). 
The speed at which animals move past each worker has been federally regulated since 1981 (fully 75 years after the Jungle-inspired Federal Meat Inspection Act of 1906) (Office of the Federal Register, 1981). Yet line speed is not set by an agency that oversees worker safety; it is set by the USDA, which regulates food safety. While worker safety and food safety would seem to be complementary concerns, the USDA claimed under the Trump administration to not have "authority" to "regulate issues related to establishment worker safety" (Safety \& Health Magazine, 2019). In September 2019 the USDA issued a new rule to revoke any maximum speed limits, replacing them with an "optional New Swine Slaughter Inspection System."

The National Pork Producers Council, which lobbies for pork companies and contributes money to congressional campaigns through its PorkPAC, lauded the new (and optional) system as an effort "to ensure a safe supply of wholesome American pork" (NPPC, 2020). The Council supports the new voluntary program, which shifts many of the inspection responsibilities to companies' employees, who are not required to receive training (Food Safety News, 2020). Indeed, the new rule seeks to reduce the number of government inspectors in pork plants by 40 percent, saving the USDA up to $\$ 6$ million per year (Levitt, 2019). Plants that voluntarily adopt the new inspection system are authorized to eliminate chain line speeds.

Workers and advocates do fight back, and always have. What's more, "the state" also includes actors and organizations that seek to operationalize worker-centric concerns. In a dialectic process, there is resistance and contingency to the conflicts between capital and labor. Labor unions sued the USDA in December 2019 for refusing to address concerns about the impacts of this rule on workers. The lawsuit stated that, "In issuing the rule, USDA did not dispute the massive amount of evidence in the record showing that eliminating maximum line speeds would put the life and safety of thousands of workers at risk" (Safety \& Health Magazine, 2019). The head the USDA's Food Safety Inspection Service rejoined that claims like this from "special interest groups" reflect "emotion, hearsay," and a "fear of change" (Food Safety News, 2020). A federal district court ruled in March 2021 that the USDA does, in fact, have to take workers' safety into account in setting line speed limits (Fatka, 2021).

It can be tempting to lay chain speeds and injuries all at the feet of greedy pork packing corporations. The state, though, allows and demands that workers be faced with working conditions that even other state actors recognize as damaging to both the sustainability of the workforce and the legitimacy of existing worker protections. OSHA, which was created by Congress in 1970 to "ensure safe and healthful working conditions" for workers (OSHA, n.d.), has long documented the hazardous working conditions in meatpacking plants. This is performative, as such documentation has not translated into regulatory action. During the coronavirus pandemic, for example, when hundreds of meatpacking workers who were made to continue working in close quarters without protective equipment ultimately died (Ken \& León, 2021), OSHA was constrained by the President from making anything more than "recommendations" for the industry. To our knowledge, no pork industry firm has been held liable for any worker's COVID-related death (Grabell \& Grabell, 2021). In fact, OSHA weakened the requirements for reporting workers' deaths during the pandemic, and has reportedly "not inspected 26 out of the 65 meatpacking plants 
where reporters found at least one worker died of COVID-19" (Bagenstose et al., 2021).

The notions that a USDA head could call workers in these plants a "special interest group" and that OSHA would weaken regulations during a pandemic call into question the effectiveness of state agencies in protecting the workers who make these industries both possible and profitable, and the larger population who eats what they make. These agencies seem, in fact, to serve the accumulation-centered agendas of the industry in fairly plain ways, reflecting in part what criminologists have previously called "food fraud" (León \& Ken, 2019).

It is tempting to view the activities of OSHA and the USDA as limited examples of regulatory failure - too few investigators, too little funding, not enough support from presidential administrations. In the context of structural contradictions theory, however, state regulatory agencies should not be understood to be the "police officers" of industry. As Tombs (2012, p. 173) explains, these agencies' "relation to capital is not merely one of opposition and externality." Instead, they "play a much more general role in reproducing the social conditions necessary to sustain a capitalist social order." We further specify that this "role" requires a theatrical performance. Occasional concessions to labor can "foster an impression of good governance" through performative rituals, even when a regulatory agency has largely surrendered to capital (Ding, 2020, p. 536). Such rituals occur on highly visible stages where political and state actors must deliver on promises made to advance the material conditions of the electorate, which in turn augments the legitimacy of the state. But the trendline in the pork sector shows how state-corporate symbiosis, in material and ideological ways, provides enduring legitimacy to the project of accumulating capital even while it harms, injures, and kills workers at a rate that can be normalized as "part of doing business." The labor movement may be best situated to resist this normalization, but as we detail below, the balance of power between labor and the capitalist state has grown more asymmetrical over time.

\section{The harms of anti-union "success"}

The current balance of power between employers and workers is a conflict where the rules and rewards are both mediated and defined by the state. The Iowa Beef Processes company (IBP) is widely recognized to have fundamentally altered the meatpacking industry starting in the 1960s when it restructured bargaining, deskilled jobs, and moved packing from urban to rural areas (Horowitz, 2002). Its anti-union actions would not have been possible without ongoing local, state, and federal support. Meatpacking companies' move to rural communities was accomplished with tax breaks, grants and low-interest loans from states, modifications to sewer systems, and favorable water rates, among other amenities and incentives (Brueggemann \& Brown, 2003). The mere existence of "right-to-work states," which are designed to weaken collective labor power, is a state initiative. Further, as demonstrated above, the state has been heavily involved in coercing people to work under conditions that unions do not and would not support. 
In one telling example from 1946, 215,000 meatpacking workers across the country went on strike. After eight days, with packinghouses sitting idle, "President Truman invoked the War Labor Disputes Act on January 24, seized the packinghouses, and instructed the workers to return to the plants" (Brueggemann \& Brown, 2003, pp. 341-342). This Act had been passed to allow the executive branch to "seize" manufacturing facilities from employers during World War II, and "enable the Government to provide for changes in terms and conditions of employment" (Teller, 1946, p. 1025). "Instructing" workers to return to work-with the threat of force and the institutional capacity to deliver such force-on behalf of employers is a paragon of state-corporate symbiosis.

Still, not all arms of the state move uniformly. Executive actions carried out under this Act were interpreted by the courts more as suggestions than enforceable laws, so Congress one year later passed the Taft-Hartley Act to directly reduce union power. This legislation produced a full symbiotic mashup, allowing companies to seek court injunctions and permitting the government to sue union officials for violating their contracts with employers. Taft-Hartley also created the right-to-work infrastructure; "outlawed mass picketing, secondary boycotts, and closed shops; required a 60- day advance notice of strikes; and compelled union leaders to sign affidavits denying any association with communism" (Brueggemann \& Brown, 2003, p. 342). This would be a precursor to wholesale efforts to conflate unions (i.e., threats to capital) with threats to the nation state itself.

To be clear, the threat and actual use of violence is a fundamental feature of the modern liberal state. When we claim that the state (in its highest executive offices and in its time-tested structures) has never fought alongside unions to secure dignified working conditions, we mean this literally. We are unfamiliar with any example where state forces (i.e., police, national guard) have exchanged gunfire with private security forces (e.g., Pinkertons) on behalf of worker's rights. We do, however, know of plenty of cases where state forces have either directly killed or indirectly supported violence against workers as part of anti-union or anti-labor suppression. ${ }^{4}$

It was the federal government-not the meatpacking companies, directlyimpeding the union from gaining contract concessions from employers via the 1946 strike. More broadly, the courts barred picketing at some plants, which effectively reopened them, and striking workers "faced armed troops in many packing centers": police in Chicago and the National Guard in St. Paul, Sioux City, and Waterloo, where-in "what can only be described as hand-to-hand combat"-troops broke through picket lines to escort scabs to the meatpacking floor (Halpern, 1997, p. 230).

Major strikes later in the twentieth century yielded similar results, the most notorious being the 1985 Hormel strike in Austin, Minnesota. After Hormel froze wages in 1977 and then called for a 23 percent pay reduction eight years later, one thousand workers walked off their jobs for six months. In response, the governor of the

\footnotetext{
${ }^{4}$ Examples include the Morewood Massacre of 1891; the Leadville Miners' Strike of 1896-1897; the Lattimer Massacre of 1897; Colorado Labor Wars of 1903-1904; the Ludlow Massacre of 1914, among many instances of state-sanctioned violence that are mostly absent from dominant historical discourses (Lipold \& Isaac, 2009).
} 
state eventually ordered 800 National Guard troops to secure access to the plant, and they stayed in place for over a month (Kuhle et al., 1992). "The union didn't have the state on its side," said one newspaper account. "The workers had the audacity to put their bodies on the line to shut down the plant for nearly six months, but once Democratic Gov. Rudy Perpich called out the Minnesota guard, the strike was over" (Perl, 1986).

Brueggemann and Brown (2003) have argued that legislation and court decisions were not as influential in de-unionizing the industry as the spatial impediments to labor organizing that came with the industry's move to decentralized, rural locations. However, the ability of companies to secure tax breaks, loans, and infrastructural support from states and localities is - as much as federal laws, courts, and troopsa vital bit of state intervention that empowers corporations to enact and maintain domination over the labor market. The geo-political features of meatpacking, paired with the anti-union regulatory climate most favorable to employers, reinforce the conditions under which laborers are subject to both acute harms in the workplace and structural violence in the form of direct state action to undermine unions.

Anti-union activities are perhaps the epitome of state-corporate symbiosis, requiring much long-term "softening up" (Tombs, 2012) but also presenting themselves directly in the light of day. Whereas antitrust activity occurs at the level of line-by-line details of hundred-year-old legislation, the anti-union theater is quite visible: the state woos pork packing companies; the industry racks up incentives and sets "efficient" working conditions; and when workers protest, the state coerces them to abide by the industry's terms. Addressed by Ken and León (2021)(2021, institutional racism also factors heavily into state-corporate processes of molding a low-cost and precariously replaceable labor force. Today about 25 percent of workers in meatpacking plants are Black, and in some plants more than 90 percent of workers are immigrants and refugees from Asia, Africa, and Central America (Cohen, 2017; Fremstad et al., 2020). De jure segregation, anti-Black and -immigrant labor practices, and asymmetrical immigration laws and policies have influenced the occupational features of meatpacking work sites. In symbiotic fashion, the white and propertied electorate reap the benefits of white supremacy and low-cost pork products, while corporate enterprises reap the profits and the capitalist state enhances its position.

\section{Structural contradictions revisited}

In this paper we have demonstrated that the state and the pork industry have a symbiotic relationship that prioritizes capital. The pork industry can most readily accumulate when it is concentrated, when it prioritizes efficiency over safety and health, and when it can set up operations in places where labor will be plentiful and replaceable but not unionized. The state, in sometimes contradictory and contested ways, uses law, executive power, force, regulatory "failure," and incentives to secure these processes. Rather than call these "checkered reforms" or "incremental progress," we call them performative governance. 
As a theoretical model and an explanatory tool, structural contradictions theory accounts for the repeated occasions where the state joins with corporations in ways that harm the populace. The theory begins from the premise that a state's primary interest is to maintain or improve its position among other states, whether through violence, hegemony, or other means, which in the US requires the ongoing reproduction of the capitalist social order. This reproduction inevitably produces harm, and criminal law is an attempt to resolve the conflicts that arise in pursuit of this overarching goal. But laws, which by definition must be codified by the state, cannot fully operate in the interest of any entity that detracts from the state's primary interest in capital accumulation. Thus, we have "harms" - injurious actions and events that can only be legally permitted when the relationship between corporations and the state is symbiotic.

In the case of the pork industry, law has indeed been a source of both harm and harm reduction. Important legislative, judicial, and policy gains have occurred that contradict pork industry interests. Yet as we have demonstrated, even when such gains occur, they generally fail to address the underlying and fundamental political economic pressures and mandates of an industry that generates hundreds of billions of dollars a year. Instead, according to structural contradictions theory, such gains are performative concessions that neutralize existing dilemmas but retain the core criminogenic features of corporations, the state, and the relationship between them. When we frame the state-corporate behemoths in the U.S. pork packing industry as criminogenic, we are making a structural critique. Both the regulatory "failures" we have demonstrated, and the favorable regulatory and legislative ecosystems made possible by the state are beneficial to the shared project of capital accumulation.

For these reasons, the state cannot be relied upon to eliminate the fundamental contradiction between the need to ensure the well-being of the populace and the need to accumulate capital (Pulido et al., 2016). We do not wish to inadvertently devalue advocates' attempts over hundreds of years to band together, draw attention to harmful, discriminatory, and downright evil practices in the pork industry, and doggedly pursue better regulations, clearer legal definitions, judicial remedies, and proscriptive policy in this realm (e.g., Food \& Water Watch, 2019; National Sustainable Agriculture Coalition, 2021). We certainly do not suggest that they stop what they are doing to make the food system better for workers, farmers, eaters, animals, and the planet. Yet the evidence of state-corporate symbiosis in the pork sector and the decades upon decades of struggle tell us that the capitalist state's concern with the conditions of laborers, and with social and environmental ecologies, is structurally designed to be performative more than substantive.

A collective, radical, and criminological interrogation of industrial food systems and their legitimized harms may align with anti-capitalist movements underway (Sultana, 2021), underscored by the demands of the Black Lives Matter movement to radically reign in state power (Issar, 2021), the work of climate activists for a regenerative economy (Indigenous Environmental Network, 2020), and calls to erase the citizen/non-citizen divide (Sharma, 2020). Models exist for gift economies (Vaughan, 2018), worker-governed cooperatives (Upright, 2020), doughnut economies (Raworth, 2017), reciprocal labor practices (Daughters, 2016), convivial economies (Karides, 2021), democratic socialism (Kaufman, 2012), and others. 
Each of these in some way focuses on prioritizing the ability of people, animals, and the environment to thrive - an idea that has gained traction in the aftermath of the coronavirus pandemic (see Bittman, 2021). The symbiosis we have explored here between corporations and the state in the pork industry demands consideration of alternatives to capitalism like these, and for academic and research-related discourses on food systems to further integrate these perspectives in otherwise "valuefree" empirical analysis.

There is almost nothing ecologically or ethically coherent about industrial food systems. Almost any human mother who has ever lived knows that it is not only possible but completely ordinary to get people fed every day without systematically harming others, and yet the food systems on which we depend are by their very nature harmful and criminogenic. By tackling the state's complicity in producing this harm and explaining that complicity with a reminder that capital accumulation is the shared goal of performative governance and a profit-maximizing industry, we raise serious doubts about the ability of the capitalist state to ever align with the most rudimentary definition of democracy.

\section{References}

Ackerman, Z., \& Musil, R. K. (2018). An introduction to research and action on industrial hog production (p. 28). Rachel Carson Council.

Bagenstose, K., Chadde, S., \& Axon, R. (2021, January 11). COVID-19 deaths go uninvestigated as OSHA takes a hands-off approach to meatpacking plants. USA Today News. https://www.usatoday. com/in-depth/news/2021/01/11/covid-19-deaths-not-investigated-osha-meatpacking-plants/65375 24002/. Accessed 1 Jun 2021.

Bernat, I., \& Whyte, D. (2017). State-corporate crime and the process of capital accumulation: mapping a global regime of permission from Galicia to Morecambe Bay. Critical Criminology, 25(1), 71-86. https://doi.org/10.1007/s10612-016-9340-9

Bittman, M. (2021). Animal, vegetable, junk: A history of food, from sustainable to suicidal. Harvest.

Brueggemann, J., \& Brown, C. (2003). The decline of industrial unionism in the meatpacking industry: Event-structure analyses of labor unrest, 1946-1987. Work and Occupations, 30(3), 327-360. https://doi.org/10.1177/0730888403253912

Bureau of Labor Statistics. (2018). Standard occupational classification manual. https://www.bls.gov/ soc/2018/soc_2018_manual.pdf. Accessed 1 Oct 2020.

Chambliss, W. J. (1975). Toward a political economy of crime. Theory and Society, 2(2), 149-170.

Chambliss, W. J. (1979). On Lawmaking. British Journal of Law and Society, 6(2), 149-171. https://doi. org/10.2307/1409765

Chambliss, W. J. (1989). State-organized crime 1988 presidential address. Criminology, 27(2), 183-208.

Chambliss, W. J. (2009). State-organized crime. In Crimes of the Powerful: A Reader. Edited by David Whyte (pp. 51-53). Open University Press.

Chambliss, W. J., \& Seidman, R. B. (1971). Law. Addison-Wesley.

Chambliss, W. J., \& Zatz, M. S. (1993). Making law: The state, the law, and structural contradictions. Indiana University Press.

Cheng, H. (2012). Cheap capitalism a sociological study of food crime in China. British Journal of Criminology, 52(2), 254-273. https://doi.org/10.1093/bjc/azr078

Chrisman, S. (2020). The foodprint of pork. FoodPrint. https://foodprint.org/reports/the-foodprint-ofpork/. Accessed 31 Oct 2020.

Cohen, P. (2017, May 29). Immigrants Keep an Iowa meatpacking town alive and growing. The New York Times. https://www.nytimes.com/2017/05/29/business/economy/storm-lake-iowa-immigrant-worke rs.html. Accessed 1 Oct 2020. 
Corey, L. (1950). Meat and man: A study of monopoly, unionism, and food policy. Viking Press.

Croall, H. (2013). Food crime: A green criminology perspective. In Routledge International Handbook of Green Criminology, Nigel South and Avi Brisman, eds. Routledge.

Daughters, A. (2016). Southern Chile's Archipelago of Chiloé: Shifting identities in a new economy. The Journal of Latin American and Caribbean Anthropology, 21(2), 317-335. https://doi.org/10.1111/ jlca.12199

Dillard, J. (2008). A slaughterhouse nightmare: psychological harm suffered by slaughterhouse employees and the possibility of redress through legal reform note. Georgetown Journal on Poverty Law \& Policy, 15(2), 391-408.

Ding, I. (2020). Performative governance. World Politics, 72(4), 525-556. https://doi.org/10.1017/S0043 887120000131

Douglas, L. (2019, November 7). More antitrust lawsuits hit the meat industry. This time, it's pork. Food and Environment Reporting Network. https://thefern.org/ag_insider/more-antitrust-lawsuits-hit-themeat-industry-this-time-its-pork/. Accessed 1 Oct 2020.

Edsall, T. B. (1985). The New Politics of Inequality. W. W. Norton \& Company.

Fatka, J. (2021, April 1). Court issues stay on hog slaughter inspection rule. National Hog Farmer. https://www.nationalhogfarmer.com/regulatory/court-issues-stay-hog-slaughter-inspection-rule. Accessed 1 Oct 2020.

Federal Trade Commission. (1920). Annueal report of the federal trade commission 1919. 66th Congress, 2nd Session. U.S. House of Representatives. Document No. 751, 217.

Fitzgerald, A. J. (2009). "It's a horrible coincidence": Corporate responsibility and the 2007 pet food recall. Critical Criminology, 17(3), 195-215. https://doi.org/10.1007/s10612-009-9078-8

Fitzgerald, A. J. (2010). A social history of the slaughterhouse: From inception to contemporary implications. Human Ecology Review, 17(1), 58-69. JSTOR.

Food \& Water Watch. (2011). Meatpacker concentration harms farmers, workers and consumers: Proposed USDA livestock rule can strengthen rural economies. Food \& Water Watch. https://www. foodandwaterwatch.org/sites/default/files/meatpacker_concentration_ib_nov_2011.pdf. Accessed 1 Oct 2020.

Food \& Water Watch. (2019, September 25). Food \& water watch asks USDA for real solutions to chronic meat inspector staffing. Food \& Water Watch. https:/www.foodandwaterwatch.org/news/ food-water-watch-asks-usda-real-solutions-chronic-meat-inspector-staffing. Accessed 1 Oct 2020.

Food Safety News. (2020, January 10). What's behind the New Swine Slaughter Inspection System? [Seattle]. Food Safety News. https://www.foodsafetynews.com/2020/01/whats-behind-the-newswine-slaughter-inspection-system/

Fremstad, S., Rho, H. J., \& Brown, H. (2020, April 29). Meatpacking workers are a diverse group who need better protections. Center for Economic and Policy Research. https://cepr.net/meatpackingworkers-are-a-diverse-group-who-need-better-protections/. Accessed 1 Oct 2020.

Friedrichs, D. O., \& Rothe, D. L. (2020). Regulatory rollback and white-collar crime in the era of trump: The challenges of perspective. Journal of White Collar and Corporate Crime, 1(2), 95-102. https:// doi.org/10.1177/2631309X20912714

Genoways, T. (2014). The chain: Farm, factory, and the fate of our food. Harper Collins.

Gordon, N., \& Green, P. (2021). State crime, structural violence and Covid-19. State Crime, 10(1), 4-15,190-191.

Grabell, B., \& Grabell, M. (2021, February 4). After hundreds of meatpacking workers died from COVID-19, Congress wants answers. ProPublica. https://www.propublica.org/article/after-hundr eds-of-meatpacking-workers-died-from-covid-19-congress-wants-answers?token=--sanitized. Accessed 1 Jun 2021.

Gunderson, R. (2011). The metabolic rifts of livestock agribusiness [M.A., University of Wyoming]. In ProQuest Dissertations and Theses. http://search.proquest.com/docview/864043130/abstract/ F1EBD279D52B4C78PQ/1. Accessed 1 Oct 2020.

Gutierrez, J. (2018, November 15). JBS USA Settles \$4 Million Discrimination Case. Career Resources, Inc. https://www.crincorporated.com/jbs-usa-settles-4-million-discrimination-case/. Accessed 1 Oct 2020.

Haley, M. (2021, May). Livestock, dairy, and poultry outlook: May 2021 Summary. USDA Economic Research Service, Market Outlook. https://www.ers.usda.gov/topics/animal-products/hogs-pork/ market-outlook/. Accessed 1 Aug 2021.

Halpern, R. (1997). Down on the killing floor: Black and White workers in Chicago's packinghouses, 1904-54. University of Illinois Press. 
Harvey, D. (2007). A brief history of neoliberalism. Oxford University Press, Incorporated. http://ebook central.proquest.com/lib/gwu/detail.action?docID=422896. Accessed 1 Oct 2020.

Hillyard, P., \& Tombs, S. (2007). From 'crime' to social harm? Crime, Law and Social Change, 48(12), 9-25. https://doi.org/10.1007/s10611-007-9079-Z

Hiltzik, M. (2020, May 5). Column: A century later, meatpacking plants still resemble Upton Sinclair's depiction in “The Jungle.” Los Angeles Times. https://www.latimes.com/business/story/ 2020-05-05/meat-packing-plants-the-jungle-coronavirus. Accessed 1 Oct 2020.

Horowitz, R. (2002). The decline of unionism in America's meatpacking industry. Social Policy, 32(3), 32-36.

Human Rights Watch. (2005). Blood, Sweat, and Fear: Workers' Rights in U.S. Meat and Poultry Plants (Human Rights Watch Report, January 2005). https://www.hrw.org/reports/2005/usa01 05/. Accessed 1 Oct 2020.

Human Rights Watch. (2019a, September 4). US: Meatpacking workers' rights under threat. Human Rights Watch. https://www.hrw.org/news/2019/09/04/us-meatpacking-worke rs-rights-under-threat

Human Rights Watch. (2019b). “When we're dead and buried, our bones will keep hurting." https:// www.hrw.org/report/2019/09/04/when-were-dead-and-buried-our-bones-will-keep-hurting/ workers-rights-under-threat. Accessed 1 Oct 2020.

Indigenous Environmental Network. (2020, June 10). A people's orientation to a regenerative economy. Indigenous environmental network. https://www.ienearth.org/regenerativeeconomy/. Accessed 25 Sep 2020.

Issar, S. (2021). Listening to Black lives matter: Racial capitalism and the critique of neoliberalism. Contemporary Political Theory, 20(1), 48-71. https://doi.org/10.1057/s41296-020-00399-0

Kandel, W., \& Parrado, E. A. (2005). Restructuring of the US meat processing industry and new hispanic migrant destinations. Population and Development Review, 31(3), 447-471. JSTOR.

Kansas Department of Agriculture. (2020). 2020 Kansas Ag Growth. Kansas Department of Agriculture. https://agriculture.ks.gov/AgGrowthStrategy/ag-summit-2020. Accessed 1 Oct 2020.

Karides, M. (2021). Sappho's legacy: Convivial economics on a Greek isle. State University of New York Press.

Kaufman, C. C. (2012). Getting past capitalism: History, vision, hope. Lexington Books.

Kauzlarich, D., Mullins, C. W., \& Matthews, R. A. (2003). A complicity continuum of state crime. Contemporary Justice Review, 6(3), 241-254.

Kelloway, C., \& Miller, S. (2019). Food and power: Addressing monopolization in America's food system. Open Markets Institute. https://www.openmarketsinstitute.org/publications/food-power-addre ssing-monopolization-americas-food-system. Accessed 1 Oct 2020.

Ken, I., \& León, K. S. (2021). Necropolitical governance and state-corporate harms: COVID-19 and the U.S. Pork Packing Industry. Journal of White Collar and Corporate Crime, Online First, April 2021. https://doi.org/10.1177/2631309X211011037

Khan, L. (2012, November 9). Obama's game of chicken. Washington Monthly, November/December 2012. https://washingtonmonthly.com/magazine/novdec-2012/obamas-game-of-chicken/. Accessed 1 Oct 2020.

Knox, R. (2020, May 4). Monopolies in Meat: Endangering Workers, Farmers, and Consumers. The American Prospect. https://prospect.org/api/content/8b93fb0c-8c0b-11ea-ab3f-1244d5f7c7c6/. Accessed 1 Oct 2020.

Kolko, G. (1963). The triumph of conservatism. Free Press.

Kramer, R. C. (2016). State-organized crime, international law and structural contradictions. Critical Criminology; Dordrecht, 24(2), 231-245. http://dx.doi.org.proxy.libraries.rutgers.edu/https://doi. org/10.1007/s10612-015-9306-3

Kramer, R. C., Michalowski, R. J., \& Kauzlarich, D. (2002). The origins and development of the concept and theory of state-corporate crime. Crime \& Delinquency, 48(2), 263-282. https://doi.org/10. $1177 / 0011128702048002005$

Kuhle, B., Knox, K., \& Ross, W. H. (1992). The hormel strike at Austin, Minnesota. International Journal of Conflict Management, 3(1), 45-68. https://doi.org/10.1108/eb022706

Lander, L., Sorock, G. S., Stentz, T. L., Eisen, E. A., Mittleman, M., Hauser, R., \& Perry, M. J. (2010). A case-crossover study of occupational laceration injuries in pork processing: Methods and preliminary findings. Occupational and Environmental Medicine, 67(10), 686-692. https://doi.org/10. 1136/oem.2009.048611 
Lauck, J. (1999). Toward an Agrarian antitrust: A new direction for agricultural law. North Dakota Law Review, 75(3), 449-508.

Leighton, P. (2016). Mass salmonella poisoning by the peanut corporation of America: State-corporate crime involving food safety. Critical Criminology, 24(1), 75-91. https://doi.org/10.1007/ s10612-015-9284-5

León, K. S. (2021). Latino criminology: Unfucking colonial frameworks in 'Latinos and crime' scholarship [Application/pdf]. Critical Criminology. https://doi.org/10.7282/T3-0ZTZ-T895

León, K. S., \& Ken, I. (2017). Food fraud and the partnership for a 'Healthier' America: A case study in state-corporate crime. Critical Criminology, 25(3), 393-410. https://doi.org/10.1007/ s10612-017-9363-X

León, K. S., \& Ken, I. (2019). Legitimized fraud and the state-corporate criminology of food - a spectrum-based theory. Crime, Law and Social Change, 71(1), 25-46. https://doi.org/10.1007/ s10611-018-9787-6

Levitt, T. (2019, September 18). US moves to scrap speed limits on pig slaughter lines. The Guardian. https://www.theguardian.com/environment/2019/sep/18/us-moves-to-scrap-speed-limits-on-pigslaughter-lines. Accessed 1 Oct 2020.

Lilliston, B. (2017, October 17). Trump's USDA does bidding of meatpackers, turns back on farmers \& ranchers. Institute for Agriculture \& Trade Policy. https://www.iatp.org/blog/201710/trumps-usdadoes-bidding-meatpackers-turns-back-farmers-ranchers

Lipold, P. F., \& Isaac, L. W. (2009). Striking deaths: Lethal contestation and the "Exceptional" Character of the American labor movement, 1870-1970*. International Review of Social History, 54(2), 167-205. https://doi.org/10.1017/S0020859009000674

Lord, N., Flores Elizondo, C. J., \& Spencer, J. (2017). The dynamics of food fraud: The interactions between criminal opportunity and market (dys)functionality in legitimate business. Criminology \& Criminal Justice, 17(5), 605-623. https://doi.org/10.1177/1748895816684539

Matthews, R. A., \& Kauzlarich, D. (2007). State crimes and state harms: A tale of two definitional frameworks. Crime, Law and Social Change, 48(1-2), 43-55. https://doi.org/10.1007/ s10611-007-9081-5

Michalowski, R. J. (2016). What is crime? Critical Criminology, 24(2), 181-199. https://doi.org/10.1007/ s10612-015-9303-6

Michalowski, R. J., \& Kramer, R. C. (Eds.). (2006). State-corporate crime: Wrongdoing at the intersection of business and government. Rutgers University Press.

Mills, C. W. (1956). The Power Elite. Oxford University Press.

Mock, S. (2020, October 27). How does one of the world's biggest pork firms go bust during a boom? The Guardian. http://www.theguardian.com/environment/2020/oct/27/how-does-one-of-theworlds-biggest-pork-firms-go-bust-during-a-boom. Accessed 1 Jun 2021.

National Sustainable Agriculture Coalition. (2021, February 17). Undo the packers and stockyards "Undue Preference" Final Rule. NSAC's Blog. https://sustainableagriculture.net/blog/undo-thepackers-and-stockyards-undue-preference-final-rule/. Accessed 1 Jun 2021.

NELP. (2018). Take action to reduce worker health risks to anti-microbial chemical in meat plants. National Employment Law Project. https://www.nelp.org/publication/take-action-reduce-workerhealth-risks-anti-microbial-chemical-meat-plants/. Accessed 1 Oct 2020.

NPPC. (2020). New swine inspection system I national pork producers council. National Pork Producers Council. https://nppc.org/issues/issue/haccp-inspection-models-project-himp/

Office of the Federal Register. (1981). Federal Register. National Archives and Records Service, General Services Administration. https://tile.loc.gov/storage-services/service/11/fedreg/fr046/fr046167/ fr046167.pdf. Accessed 1 Oct 2020.

OSHA. (n.d.). Safety and health topics I Meat Packing Industry I Occupational Safety and Health Administration. Retrieved May 29, 2020, from https://www.osha.gov/SLTC/meatpacking/

Pearce, F. (1976). Crimes of the powerful: Marxism, crime, and deviance. Pluto Press.

Perl, P. (1986, February 16). The Hormel strike was doomed. Washington Post. https://www.washington post.com/archive/opinions/1986/02/16/the-hormel-strike-was-doomed/eaf87a1c-b393-44d7-aedd$6316 \mathrm{~cd} 8078 \mathrm{e} 9 /$. Accessed 1 Oct 2020.

Philpott, T. (2021, February 25). Why do meatpacking workers face such gruesome conditions? Mother Jones. https://www.motherjones.com/food/2021/02/meatpack-food-lobby-coronavirus/. Accessed 1 Jun 2021. 
Pulido, L., Kohl, E., \& Cotton, N.-M. (2016). State regulation and environmental justice: the need for strategy reassessment. Capitalism Nature Socialism, 27(2), 12-31. https://doi.org/10.1080/10455 752.2016 .1146782

Quinney, R. (1970). The social reality of crime. Little Brown \& Company.

Raworth, K. (2017). Doughnut economics: Seven ways to think like a 21st-Century Economist. Chelsea Green Publishing.

Rodriguez, L. J., \& Barlow, D. E. (1999). Structural contradictions and the United States Sentencing Commission. Crime, Law and Social Change, 32(2), 169-202. https://doi.org/10.1023/A:10083 93510266

Safety and Health Magazine. (2019, October 9). Labor unions sue USDA over final rule that eliminates pork-processing line speeds. https://www.safetyandhealthmagazine.com/articles/18985-laborunions-sue-usda-over-final-rule-that-eliminates-pork-processing-line-speeds. Accessed 1 Oct 2020.

Schwendinger, H., \& Schwendinger, J. (1970). Defenders of order or guardians of human rights? Issues in Criminology, 5(2), 123-157.

Sharma, N. (2020). Home Rule: National Sovereignty and the Separation of Natives and Migrants. Duke University Press. https://bookshop.org/books/home-rule-national-sovereignty-and-the-separationof-natives-and-migrants/9781478000952. Accessed 1 Oct 2020.

Spink, J., \& Moyer, D. C. (2011). Defining the public health threat of food fraud. Journal of Food Science, 76(9), R157-R163. https://doi.org/10.1111/j.1750-3841.2011.02417.x

Stake, R. E. (2005). Qualitative Case Studies. In The SAGE Handbook of Qualitative Research.

Stoll-Kleemann, S., \& O'Riordan, T. (2015). The sustainability challenges of our meat and dairy diets. Environment: Science and Policy for Sustainable Development, 57(3), 34-48. https://doi.org/10. 1080/00139157.2015.1025644

Sultana, Z. (2021, January 23). Why anti-racism must be anti-capitalist. Tribune. https://tribunemag.co. uk/2021/01/why-anti-racism-must-be-anti-capitalist. Accessed 1 Jun 2021.

Teller, L. (1946). Government seizure in labor disputes. Harvard Law Review, 60(7), 1017-1059.

Tilman, D., \& Clark, M. (2014). Global diets link environmental sustainability and human health. Nature, 515(7528), 518-522. https://doi.org/10.1038/nature13959

Tombs, S. (2012). State-Corporate Symbiosis in the Production of Crime and Harm. State Crime Journal, 1(2), 170-195. JSTOR.

Tombs, S., \& Whyte, D. (2015). The corporate criminal: Why corporations must be abolished. Routledge.

Upright, C. B. (2020). Grocery activism: The radical history of food cooperatives in Minnesota. University of Minnesota Press.

USDA. (2017). 2016 Packers and stockyards program annual report. https://www.gipsa.usda.gov/psp/ publication/ar/2016_psp_annual_report.pdf. Accessed 1 Oct 2020.

Vaughan, G. (2018). The maternal roots of the gift economy. Inanna Publications and Education Inc. http://ebookcentral.proquest.com/lib/gwu/detail.action?docID $=5787684$

Virtue, G. O. (1920). The Meat-Packing Investigation. The Quarterly Journal of Economics, 34(4), 626. https://doi.org/10.2307/1885160

Ward, C. (2010). Economics of competition in the U.S. Livestock Industry. justice.gov. https://www.justi ce.gov/sites/default/files/atr/legacy/2011/09/09/AGW-15639-a.pdf. Accessed 1 Oct 2020.

Ward, G. (2015). The slow violence of state organized race crime. Theoretical Criminology, 19(3), 299314. https://doi.org/10.1177/1362480614550119

Warren, D. (2020, May 6). Hotspots: Prisons and slaughterhouses hit rural communities hard. Nonprofit Quarterly. https://nonprofitquarterly.org/hotspots-prisons-and-slaughterhouses-hit-rural-commu nities-hard/. Accessed 1 Oct 2020.

Wendee, N. (2013). CAFOs and environmental justice: The case of North Carolina. Environmental Health Perspectives, 121(6), a182-a189. https://doi.org/10.1289/ehp.121-a182

Wing, S., \& Johnston, J. (2014). Industrial hog operations in North Carolina disproportionately impact African-Americans. University of North Carolina.

Woodall, P., \& Shannon, T. L. (2018). Monopoly power corrodes choice and resiliency in the food system. The Antitrust Bulletin, 63(2), 198-221. https://doi.org/10.1177/0003603X18770063

Publisher's note Springer Nature remains neutral with regard to jurisdictional claims in published maps and institutional affiliations. 